\title{
PENGARUH KUALITAS LAYANAN TERHADAP NILAI PELANGGAN, KEPUASAN PELANGGAN DAN LOYALITAS PELANGGAN (Studi pada Klinik dr. Sumakto, Sp. A(K) di Malang)
}

\author{
${ }^{1)}$ Yekti Asmoro Kanthi, ${ }^{2)}$ Suharyono, ${ }^{3)}$ Srikandi Kumadji \\ ${ }^{123)}$ Fakultas Ilmu Administrasi Universitas Brawijaya \\ ${ }^{1)}$ Email: yektiasmorokanthi@gmail.com
}

\begin{abstract}
Service quality is crucial to the service providers to maintain markets in the long run. Good service quality will earn customers' positive feedback. This research is conducted to find out and explain whether there a significant correlation between service quality, customers' value, customers' satisfaction and customers' loyalty. This research utilizes Partial Least Square (PLS) technic analysis combined with hypothesis testing to examine the effect of the treatment to the determined variables. This research uses explanatory research with 60 sampel in health pediatric clinic Malang. Sampling technique used probability sampling with sistematic sampling approaching. The findings of the research indicate that service quality retains a significant effect to the customers' value, customers' satisfaction and customers' loyality. The customers' value correlates significantly to the customers' satisfaction and customers' loyality. The customers' satisfaction correlates not significantly to the customers' loyalty. Key words: services quality, customers' value, satisfaction, customers' loyalty, health pediatric clinic.
\end{abstract}

Keywords: service quality, customer value, satisfaction, customer loyalty and child health clinics.

\begin{abstract}
ABSTRAK
Kualitas layanan merupakan kunci utama bagi suatu instansi jasa untuk mempertahankan pasar dalam jangka waktu yang panjang. Kualitas layanan yang baik akan memberikan suatu nilai yang baik pula bagi pelanggan. Tujuan penelitian ini untuk mengetahui dan menjelaskan pengaruh signifikan kualitas layanan terhadap nilai pelanggan, kepuasan pelanggan dan loyalitas pelanggan. Penelitian ini menggunakan teknik analisis Partial Least Square (PLS) disertai dengan pengujian hipotesis untuk mengetahui pengaruh signifikan terhadap variabel penelitian yang telah ditentukan. Penelitian menggunakan jenis penelitian eksplanatori dengan sampel sebanyak 60 orang pada salah satu klinik kesehatan anak di kota Malang. Teknik pengambilan sampel menggunakan probabilty sampling dengan pendekatan sistematic sampling. Hasil penelitian menunjukkan kualitas layanan berpengaruh signifikan terhadap nilai pelanggan, kepuasan pelanggan dan loyalitas pelanggan. Nilai pelanggan berpengaruh signifikan terhadap kepuasan pelanggan dan loyalitas pelanggan. Kepuasan pelanggan berpengaruh tidak signifikan terhadap loyalitas pelanggan.
\end{abstract}

Kata kunci : kualitas layanan, nilai pelanggan, kepuasan, loyalitas pelanggan dan klinik kesehatan anak. 


\section{PENDAHULUAN}

Kualitas jasa dimulai dari kebutuhan pelanggan dan berakhir pada persepsi pelanggan. Pelanggan yang mengkonsumsi dan menikmati jasa dari suatu instansi dapat memberikan penilaiannya terhadap kualitas jasa. Persepsi pelanggan terhadap kualitas merupakan penilaian menyeluruh atas keunggulan suatu jasa. Kualitas layanan yang baik dapat memberikan kepuasan pada pelanggan, sehingga kualitas layanan menjadi kunci dalam upaya instansi jasa untuk mempertahankan pasar dalam jangka panjang yang membentuk loyalitas pelanggan.

Nilai dari suatu jasa ditentukan oleh pelanggan. Pelanggan akan membandingkan pengorbanan yang dikeluarkan dengan apa yang didapatkan (Kotler, 1997). Pengorbanan yang dikeluarkan oleh pelanggan dapat berupa uang, waktu, dan usaha untuk mendapatkan layanan dari penyedia jasa. Nilai bagi pelanggan juga berpengaruh terhadap pembentukan loyalitas pelanggan. Pelanggan menilai suatu produk atau layanan mampu memberikan nilai tambah kepada pelanggan maka pelanggan akan puas dengan layanan yang ditawarkan. Pelanggan yang puas terhadap layanan yang diberikan oleh suatu instansi jasa menyebabkan perilaku pembelian ulang di masa mendatang, sehingga menumbuhkan loyalitas dalam diri pelanggan. Suatu bisnis dapat dikatakan sukses jika berhasil mendapatkan, mempertahankan, dan menumbuhkan pelanggan.

Kepuasan merupakan suatu penilaian atau bentuk dari persepsi pelanggan yang menyatakan bahwa suatu layanan telah memberikan tingkat kenikmatan yang sesuai dengan harapan bahkan lebih dari yang diharapkan. Maksud dari tingkat kenikmatan adalah suatu kesesuaian antara kualitas layanan yang dirasakan dari pengalaman mengkonsumsi jasa dengan apa yang diharapkan (Palilati, 2004).

Instansi jasa kesehatan anak di Indonesia berkembang semakin pesat, hal ini menyebabkan suatu persaingan bisnis dalam instansi kesehatan anak yang semakin hari bertambah semakin ketat.
Setiap instansi jasa kesehatan dituntut untuk menciptakan keunggulan kompetitif untuk menghadapi pesaing-pesaing baru yang bergerak dalam instansi jasa yang sama sehingga harus memiliki kemampuan mengembangkan pilihan yang strategis agar dapat menyesuaikan dengan lingkungan yang dinamis.

Demikian pula dengan konteks penelitian pada klinik dr. Sumakto, Sp.A

(K), sebagai salah satu instansi yang menyediakan layanan kesehatan untuk balita dan anak-anak, maka harus

mencermati dan memahami perilaku

konsumennya karena kualitas layanan yang dihasilkan merupakan hal penting. Bayi yang baru lahir ataupun seorang balita rentan terhadap suatu penyakit. Hal ini bisa terjadi karena sistem kekebalan tubuh seorang balita kurang optimal sehingga rentan terhadap beberapa penyakit, maka balita harus diberi kekebalan dalam tubuhnya agar dapat melawan beberapa penyakit yang berbahaya dengan cara pemberian vaksinasi. Dibutuhkan suatu tenaga yang profesional untuk memberikan layanan jasa dalam hal kesehatan balita dan anak- anak yaitu seorang dokter anak yang memiliki kualitas yang baik dari segi layanannya maupun ilmu yang diberikannya kepada pasien yang datang untuk berobat, konsultasi maupun vaksinasi.

Alasan bahwa penelitian ini fokus pada klinik dr. Sumakto, Sp. A(K), didasarkan pada fenomena penting yaitu: (1) Malang sebagai sebuah kota terbesar kedua di Jawa Timur yang mulai maju dan masyarakat yang memiliki pemikiran yang lebih modern, dibutuhkan suatu sarana dan prasarana yang meyakinkan dalam hal kesehatan anak; (2) Perubahan lingkungan eksternal dan perkembangan global yang semakin pesat baik dari aspek ekonomi dan sosial, menyebabkan tingginya tuntutan kualitas layanan yang baik dan lengkap dari segi sarana dan prasarana; (3) Perubahan dalam bidang sistem informasi dan teknologi yang semakin pesat membuat semakin meningkatnya keinginan masyarakat untuk selalu update dengan informasi yang ada terutama dalam hal kesehatan anak, karena ilmu pengetahuan akan 
terus berkembang seiring dengan kemajuan jaman sehingga dibutuhkan seorang dokter dengan tingkat profesionalitas tinggi dan selalu up date akan hal-hal baru; (4) Klinik dokter Sumakto, Sp.A(K) banyak dikunjungi oleh para orang tua yang ingin berobat, konsultasi maupun vaksinasi terbukti dengan adanya pengamatan dari peneliti bahwa setiap hari pasien yang berkunjung minimal ada 20 orang. Hasil temuan dari penelitian ini akan dianalisis sehingga dapat diambil suatu kebijakan yang selanjutnya dapat bermanfaat untuk usaha klinik kesehatan anak tersebut. Berdasarkan latar belakang di atas, maka rumusan masalah dalam penelitian ini adalah :

1. Apakah kualitas layanan berpengaruh signifikan terhadap nilai pelanggan?

2. Apakah kualitas layanan berpengaruh signiifkan terhadap kepuasan pelanggan?

3. Apakah nilai pelanggan berpengaruh signifikan terhadap kepuasan pelanggan?

4. Apakah kualitas layanan berpengaruh signifikan terhadap loyalitas pelanggan?

5. Apakah nilai pelanggan berpengaruh signifikan terhadap loyalitas pelanggan?

6. Apakah kepuasan pelanggan berpengaruh signifikan terhadap loyalitas pelanggan?

\section{LATAR BELAKNG TEORI DAN HIPOTESIS \\ Kualitas Layanan}

Kualitas layanan dapat diartikan sebagai perbandingan harapan dengan persepsi kinerja sesungguhnya dari jasa (Zeithaml dan Bitner, 2003). Menurut Kotler (2002) kualitas adalah totalitas fitur dan karakteristik produk atau jasa yang mempengaruhi kemampuannya untuk memenuhi kebutuhan yang dinyatakan. Perusahaan dapat meningkatkan kepuasan pelanggan, dengan tujuan agar perusahaan dapat memaksimumkan pengalaman dari pelanggan yang menyenangkan dan meminimumkan atau meniadakan pengalaman yang kurang menyenangkan dari pelanggan.

Menurut Parasuraman et al. (1988), kualitas layanan terdiri dari lima indikator yang digunakan dalam penelitian ini. Indikator tersebut adalah sebagai berikut:

1. Bukti fisik (tangible),

2. Kehandalan (reliability),

3. Daya tanggap (responsiveness),

4. Jaminan (assurance),

5.Empati (empathy).

\section{Nilai Pelanggan}

Pelanggan memiliki kebutuhan yang sama, akan tetapi keinginan dari setiap pelanggan berbeda. Hal ini menyebabkan persepsi pelanggan terhadap produk atau jasa yang ditawarkan perusahaan akan memberikan nilai yang berbeda di mata pelanggan. Nilai adalah sesuatu yang bersifat individual karena sesuatu yang bernilai bagi seseorang belum tentu bernilai bagi orang lain. Terkadang pelanggan menilai suatu produk atau jasa berdasarkan manfaat produk atau jasa tersebut, tetapi di lain situasi pelanggan menilai suatu produk atau jasa berdasarkan layanan atau keramahan karyawan dalam melayani pelanggan tanpa mempedulikan manfaat dari produk atau jasa tersebut.

Tingkat kepuasan pelanggan dapat ditentukan ketika seorang pelanggan melihat nilai lebih dari suatu produk dan kinerja layanan yang diterima dari suatu proses pembelian produk atau jasa. Besarnya nilai lebih bagi pelanggan yang diberikan oleh sebuah produk atau jasa merupakan jawaban seseorang pelanggan untuk menentukan pilihannya. Pada dasarnya pelanggan mencari nilai terbesar yang diberikan suatu produk atau jasa (Lupiyoadi, 2006).

Menurut Barnes (2003), nilai adalah suatu preferensi yang bersifat

relatif (komparatif, personal dan situasional) yang memberi ciri pada pengalaman seseorang dalam berinteraksi dengan beberapa obyek. Hal ini melibatkan transaksi antara pelanggan dan instansi atau perusahaan. Nilai melibatkan sebuah preferensi, berarti suatu kecondongan yang menguntungkan, kesukaan, pengaruh positif, atau menilai sesuatu sebagai hal yang baik. Nilai juga bersifat relatif dalam tiga hal yaitu, komparatif (membandingkan pilihan satu dengan lainnya), personal (berbeda-beda 
antara satu pelanggan dengan yang lainnya), dan situasional (sangat berbeda dari situasi ke situasi).

Pelanggan mempersepsikan bahwa suatu produk memiliki keunggulan

yang berbeda dengan produk lain dan keunggulan itu sangat berarti, maka pelanggan akan memilih produk tersebut,

walaupun sebenarnya kedua produk relatif mirip. Hal ini dikarenakan pada saat penyampaian jasa, pemberi jasa berhadapan langsung dengan pelanggan, sehingga persepsi yang diberikan pelanggan sangat berbeda-beda karena persepsi bersifat subyektif dan sangat tergantung dari keadaan yang dirasakannya pada saat melakukan kontak layanan (Lovelock, 2004). Indikator yang digunakan sebagai berikut:

1. Superioritas, yang membandingkan antara manfaat yang diterima dengan biaya yang dikeluarkan. Selain itu juga mengukur tingkat keunggulan bersaing dengan kompetitor lainnya.

2. Manfaat yang mengukur nilai kegunaan suatu produk atau jasa.

\section{Kepuasan Pelanggan}

Menurut Engel et al. (1990) dalam Tjiptono (2005) mengatakan bahwa kepuasan pelanggan merupakan evaluasi purnabeli dimana alternatif yang dipilih sekurangkurangnya sama atau melebihi harapan pelanggan, sedangkan ketidakpuasan timbul apabila hasil (outcome) tidak memenuhi harapan. Kotler (1997) mendefinisikan kepuasan pelanggan sebagai tingkat perasaan seseorang setelah membandingkan kinerja yang ia rasakan dengan harapannya. Umumnya harapan pelanggan merupakan perkiraan atau keyakinan pelanggan tentang yang akan diterima pelanggan bila membeli dan mengkonsumsi suatu produk atau jasa.

Menurut Fornell et al. (1996)

pengukuran terhadap kepuasan pelanggan, menggunakan tiga indikator dalam pengukuran kepuasan pelanggan yaitu:

1) Overall satisfaction (kepuasan pelanggan secara menyeluruh) adalah hasil evaluasi dan pengalaman konsumsi dari pelanggan yang berasal dari kebiasaan, kendala dan standarisasi layanan;

2) Confirmation of expectation (konfirmasi harapan) adalah tingkat kesesuaian antara kinerja layanan dan harapan pelanggan;

3) Comparison of ideal adalah kinerja produk atau jasa dibandingkan dengan kondisi ideal menurut persepsi pelanggan.

\section{Loyalitas Pelanggan}

Loyalitas pelanggan merupakan dorongan yang sangat penting untuk menciptakan penjualan. Pelanggan akan menjadi loyal jika pelanggan memandang perusahaan tersebut sebagai perusahaan yang baik. Di mata pelanggan, suatu perusahaan baik bila pelanggan melakukan pembelian pertama dari perusahaan, dan setelah pembelian pertama, pelanggan memiliki keinginan untuk melakukan sesuatu (Yuniningsih, 2007).

Hurriyati (2005) mengungkapkan bahwa loyalitas pelanggan mencerminkan niat berperilaku dari konsumen atas suatu produk atau jasa, dan perilaku tersebut memungkinkan pembelian ulang di masa mendatang atau pembaharuan kontrak jasa, perilaku ini juga menggambarkan seberapa mungkin pelanggan akan beralih ke penyedia layanan atau merek lainnya, serta seberapa mungkin pelanggan akan memberikan informasi yang positif kepada pihak lain. Bendapudi \& Berry (1997) dalam Tjiptono (2006), loyalitas pelanggan dalam pemasaran jasa didefinisikan sebagai respon pelanggan untuk memegang teguh komitmen yang mendasari kontinuitas relasi yang dapat tercermin pada pembelian berkelanjutan dari penyedia jasa yang sama atas dasar dedikasi. Indikator dari loyalitas adalah:

1. Rekomendasi kepada teman (recommend friend) adalah merekomendasikan produk yang telah dikonsumsi kepada teman.

2. Pembelian Ulang (continue purchasing) adalah pembelian yang dilakukan secara terus menerus terhadap produk yang telah dikonsumsi. 


\section{Kerangka Konseptual}

Kerangka konseptual dapat pada penelitian ini disajikan dalam Gambar 1.

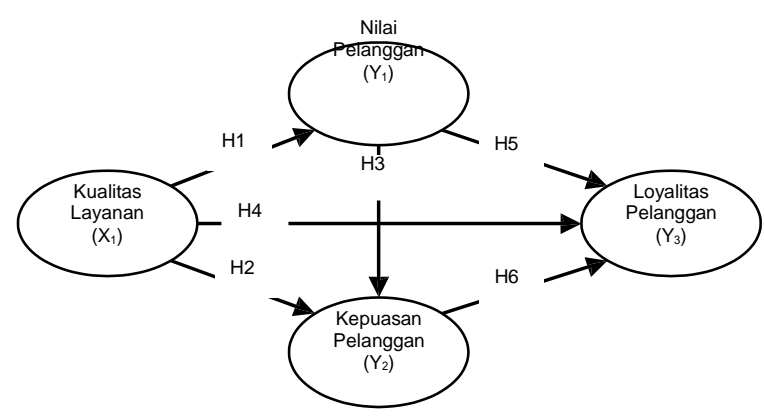

Gambar 1. Model Konseptual

H1: Kulitas layanan memiliki pengaruh terhadap nilai pelanggan.

H2: Kualitas layanan memiliki pengaruh terhadap kepuasan pelanggan.

H3: Nilai pelanggan memiliki pengaruh terhadap kepuasan pelanggan.

H4: Kualitas layanan memiliki pengaruh terhadap loyalitas pelanggan.

H5: Nilai pelanggan memiliki pengaruh terhadap loyalitas pelanggan.

H6: Kepuasan pelanggan memiliki pengaruh terhadap loyalitas pelanggan.

\section{METODE PENELITIAN}

Jenis penelitian ini termasuk dalam penelitian eksplanatori (explanatory research) yaitu penelitian yang berupaya menjelaskan hubungan kausal antara variabel-variabel melalui pengujian hipotesis (Singarimbun dan Effendi, 2008). Lokasi penelitian ini dilaksanakan di Klinik dr. Sumakto, Sp. A(K) yang berada di Jalan Tambora No. 21, Malang.

Populasi pada penelitian ini adalah seluruh pelanggan yang sedang menikmati fasilitas dan melakukan kunjungan ke klinik dr. Sumakto, Sp. A(K) di Malang. Populasi sasaran penelitian ini merupakan pelanggan yang loyal melakukan kunjungan ke dr. Sumakto, Sp. A (K). Ciri-ciri populasi sasaran penelitan ini yang menentukan bahwa responden disebut pasien yang loyal yaitu:

1. Responden adalah orang tua dari balita atau anak-anak yang melakukan kunjungan ke klinik dokter Sumakto, Sp. $\mathrm{A}(\mathrm{K})$
2. Responden adalah orang tua yang berkunjung ke klinik dokter Sumakto, Sp. $A(K)$ minimal $6 x$ dalam setahun.

Peneliti menggunakan sampel minimum 30 subyek karena sesuai dengan alat analisis yang digunakan yaitu Partial Least Square (PLS). Secara pasti, ukuran sampel dapat diketahui dengan mengalikan jumlah indikator dari 4 variabel dengan $5-10$, hal ini mengacu pendapat yang dikemukakan oleh Solimun (2003) bahwa penentuan besarnya sample size sama dengan 5 hingga 10 kali jumlah variabel manifest (indikator) dari keseluruhan variabel laten. Berdasarkan ketentuan tersebut maka besarnya sampel yang digunakan adalah $12 \times 5=60$ orang atau responden.

\section{HASIL DAN PEMBAHASAN}

Hasil Analisis Inferensial

Tabel 1. Hasil Pengujian Hipotesis

\begin{tabular}{|c|c|c|c|c|c|c|}
\hline No. & \multicolumn{2}{|c|}{$\begin{array}{l}\text { Hubungan antar } \\
\text { Variabel }\end{array}$} & $\begin{array}{l}\text { Koefisien } \\
\text { Jalur }\end{array}$ & p-valiue & Rhicung & Ket. \\
\hline 1 & $\begin{array}{l}\text { Kusitas } \\
\text { Loysran } \\
(X)\end{array}$ & $\begin{array}{l}\text { Nilai } \\
\text { Pedanggon } \\
\left(Y_{1}\right)\end{array}$ & 0,800 & 0,000 & 32,763 & Signifikan \\
\hline 2 & $\begin{array}{c}\text { Kugtas } \\
\text { Layaran } \\
\langle X\rangle\end{array}$ & $\begin{array}{c}\text { Kepuasan } \\
\text { Pelanggan } \\
\left(Y_{2}\right)\end{array}$ & 0.494 & 0,000 & 4,419 & Sigrinkan \\
\hline 3 & $\begin{array}{c}\text { Nlai } \\
\text { Pelerggan } \\
\left(\gamma_{i}\right)\end{array}$ & $\begin{array}{c}\text { Kepuasan } \\
\text { Pelanggan } \\
\left(\gamma_{2}\right)\end{array}$ & 0,461 & 0,000 & 4,168 & Segnikan \\
\hline 4 & $\begin{array}{l}\text { Rusitas } \\
\text { Layaran } \\
(x)\end{array}$ & $\begin{array}{c}\text { Loyaltas } \\
\text { Pedangan } \\
\left(Y_{1}\right)\end{array}$ & 0873 & 0,000 & 6,102 & Signtikan \\
\hline 5 & $\begin{array}{c}\text { Niai } \\
\text { Pelerggan } \\
\left(\gamma_{i}\right)\end{array}$ & $\begin{array}{c}\text { Loyaitas } \\
\text { Pelangagn } \\
\left(Y_{1}\right)\end{array}$ & $-0,322$ & 0,037 & 2.131 & Sigrifikan \\
\hline 6. & $\begin{array}{c}\text { Kepuasan } \\
\text { Pelanggan } \\
\left(\mathrm{r}_{2}\right)\end{array}$ & $\begin{array}{c}\text { Loyalitas } \\
\text { Pelangean } \\
\left(Y_{3}\right)\end{array}$ & 0,227 & 0,157 & 1,433 & $\begin{array}{c}\text { Tidak } \\
\text { signifsam }\end{array}$ \\
\hline
\end{tabular}

Keterangan Tabel :

$p$-value $<0,05$ dan $t$-hitung $>1,96$ maka $\mathrm{H} 0$ ditolak

$p$-value $>0,05$ dan $t$-hitung $>1,96$ maka $\mathrm{H} 0$ diterima

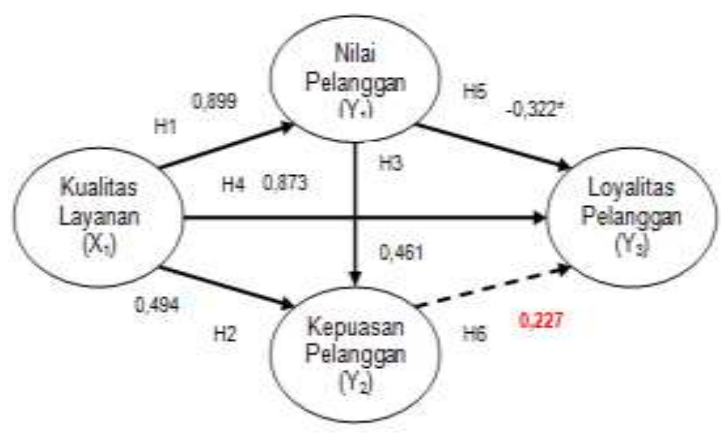

Gambar 2. Diagram Jalur Hasil Pengujian Hipotesis 


\section{Pengujian Hipotesis 1}

Kualitas layanan berpengaruh positif terhadap nilai pelanggan dengan nilai koefisien jalur sebesar 0,900 dan nilai $p$-value sebesar 0,000 ( $p$-value $<0,05$ ) serta nilai t-hitung sebesar 32,763 ( $t$ - hitung > 1,96) maka pengujian dapat dikatakan signifikan, sehingga H0 ditolak. Hal ini menunjukkan bahwa semakin baik kualitas layanan maka nilai bagi pelanggan semakin meningkat.

Kualitas layanan yang diberikan klinik dr. Sumakto, Sp. A(K) telah diakui

dan disetujui oleh mayoritas pelanggan.

Pelanggan menilai bahwa nilai dan manfaat yang dirasakan sesuai dengan pengorbanan yang telah dikeluarkan sesuai dengan kualitas layanan yang telah diberikan. Kualitas layanan yang diberikan mampu menghasilkan nilai bagi pelanggan, karena kualitas layanan tersebut menghasilkan manfaat yang lebih besar bagi pelanggan bila dibandingkan dengan pengorbanan yang telah dilakukan oleh pelanggan dalam memperoleh manfaat dari layanan tersebut. Klinik ini merupakan industri jasa, oleh karena itu layanan merupakan faktor utama dalam menciptakan nilai bagi pelanggan. Tingkat kualitas layanan yang baik sangat penting bagi suatu industri jasa agar dapat bersaing dengan para kompetitor.

Pengaruh positif dalam temuan penelitian ini memperkuat penelitian Milfener et al. (2009), Lee et al. (2011), Lertwannawit et al. (2011), Razavi dan Hossein Safari (2012). Penelitian terdahulu yang dilakukan Milfener et al. (2009) membuktikan bahwa kualitas layanan memiliki pengaruh positif dan signifikan terhadap nilai yang dirasakan pelanggan. Ketika instansi atau perusahaan jasa menyediakan layanan yang memiliki kualitas yang baik, akan meningkatkan nilai yang dirasakan bagi pelanggan. Instansi atau perusahaan jasa harus dapat menyediakan layanan yang berkualitas tingggi karena merupakan hal yang penting untuk dapat bersaing dengan para kompetitor.

Penelitian Lertwannawit et al. (2011), nilai pelanggan secara signifikan dipengaruhi oleh kualitas layanan. Ketika pelanggan mendapatkan layanan yang maksimal dari instansi atau perusahaan, nilai pelanggan juga akan lebih positif. Dalam artian bahwa jika kualitas layanan yang diberikan ditingkatkan maka nilai pelanggan juga akan meningkat. Penelitian Razavi dan Hossein Safari (2012) menyatakan bahwa kualitas layanan memiliki pengaruh yang kuat terhadap nilai pelanggan. Bahkan dalam penelitian ini, variabel kualitas layanan memiliki pengaruh paling kuat terhadap nilai pelanggan, dibandingkan variabel- variabel lainnya yaitu kepuasan dan loyalitas. Penelitian Lee et al. (2011), menyatakan bahwa kualitas layanan berpengaruh positif dan signifikan terhadap nilai pelanggan. Ketika instansi atau perusahaan mempertimbangkan, bukan hanya nilai pelanggan dari segi sifat jasa layanan saja, tetapi juga dampak akan layanan tersebut bagi pelanggan serta makna psikologis yang terkait dengan nilai pelanggan yang pada akhirnya meningkatkan kualitas layanan akan menghasilkan manfaat terbesar pada nilai pelanggan.

\section{Pengujian Hipotesis 2}

Kualitas layanan berpengaruh positif terhadap kepuasan pelanggan dengan nilai koefisien jalur sebesar 0,494 dan nilai $p$-value sebesar 0,000 ( $p$-value <

0,05 ) serta nilai $t$-hitung sebesar 4,419 (nilai $t$ hitung > 1,96) maka pengujian

dapat dikatakan signifikan, sehingga $\mathrm{H} 0$ ditolak. Hal ini menunjukkan bahwa semakin baik kualitas layanan maka kepuasan pelanggan semakin meningkat.

Kepuasan yang dirasakan oleh pelanggan klinik dr. Sumakto, Sp. A(K) terhadap jasa layanan kesehatan ditentukan dari kualitas layanan yang diberikan, semakin baik kualitas layanan yang diberikan maka berdampak pada kepuasan yang dirasakan oleh pelanggan. Hubungan kualitas layanan dan kepuasan tidak lepas dari kreativitas layanan klinik. Oleh karena itu, kepuasan pelanggan yang dirasakan terhadap jasa layanan ditentukan oleh bagaimana kualitas layanan yang diberikan.

Pengaruh positif dalam temuan penelitian ini memperkuat penelitian Tuhumena et al. (2008), Hidayat (2009), Laohasirichaikul et al. (2010), Padma et 
al. (2010), Lertwannawit et al. (2011), Chao Chan Wu (2011), Lee et al. (2011), dan Patawayati et al. (2013). Penelitian terdahulu yang dilakukan oleh Tuhumena et al. (2008) menyatakan bahwa kualitas layanan kesehatan yang ditawarkan harus sesuai dengan dengan harapan pelanggan untuk meningkatkan kepuasan. Kepuasan terjadi apabila layanan yang diberikan dapat sebanding atau bahkan melebihi harapan pelanggan.

Penelitian Hidayat (2009)

menemukan bahwa kualitas layanan berpengaruh positif dan signifikan terhadap kepuasan pelanggan. Hal tersebut menunjukkan bahwa semakin baik kualitas layanan yang diberikan oleh perusahaan maka pelanggan semakin merasa puas terhadap layanan tersebut. Hubungan kualitas layanan dan kepuasan pelanggan tidak lepas dari pembicaraan kreativitas layanan instansi atau perusahaan. Instansi atau perusahaan harus mampu mengidentifikasi siapa yang menjadi pelanggannya untuk mewujudkan suatu layanan berkualitas yang bermuara pada kepuasan pelanggan, sehingga mampu memahami tingkat persepsi dan harapan pelanggan atas kualitas layanan. Penelitian Laohasirichaikul et al. (2010) juga menyatakan bahwa kualitas layanan berpengaruh positif dan signifikan terhadap kepuasan pelanggan. Peningkatan kualitas layanan dapat menyebabkan pelanggan merasa puas. Kualitas layanan merupakan suatu kunci terbentuknya kepuasan, maka instansi atau perusahaan jasa harus mampu meningkatkan kualitas layanan baik dari sarana maupun prasarana jika ingin berhasil mempertahankan pasar.

Hasil yang sama dikemukakan oleh Padma et al. (2010) dan Lertwannawit et al. (2011), bahwa kualitas layanan berpengaruh positif dan signifikan terhadap kepuasan pelanggan. Menurut Craig et al. (2007) dalam Padma et al. (2010), kualitas layanan menerima perhatian khusus dari penyedia jasa layanan, yaitu dengan meningkatkan kualitas layanan, yang konsekuensinya kepuasan pelanggan juga akan meningkat. Kualitas layanan yang diberikan sangatlah penting untuk mendorong kepuasan pelanggan. Chao
Chan Wu (2011) mengungkapkan bahwa kualitas layanan mempengaruhi kepuasan pelanggan. Penyedia jasa harus merencanakan dan melaksanakan strategi layanan bagi pelanggan yang berorientasi untuk medis agar dengan strategi tersebut akan meningkatkan kepuasan. Penelitian Lee et al. (2011), dan Patawayati et al. (2013) menemukan bahwa kualitas layanan mempengaruhi kepuasan pelanggan. Kualitas layanan dan kepuasan dianggap sebagai dua sisi dari koin yang sama. Kepuasan merupakan perbandingan kinerja layanan dan harapan pelanggan.

\section{Pengujian Hipotesis 3}

Nilai pelanggan berpengaruh positif terhadap kepuasan pelanggan dengan nilai koefisien jalur sebesar 0,461 dan nilai $p$-value sebesar 0,000 ( $p$-value <

0,05 ) serta nilai $t$-hitung sebesar 4,416 (nilai $t$ hitung > 1,96) maka pengujian dapat dikatakan signifikan, sehingga $\mathrm{H} 0$ ditolak. Hal ini menunjukkan bahwa semakin baik nilai yang dirasakan oleh pelanggan maka kepuasan pelanggan semakin meningkat.

Klinik dr. Sumakto, Sp. A(K) dianggap mampu meningkatkan nilai lebih bagi pelanggan sehingga menciptakan rasa puas pada diri pelanggan. Kualitas, manfaat dan pengorbanan (uang, waktu dan tenaga) yang diberikan merupakan suatu cerminan dari nilai untuk mendapatkan sebuah layanan. Sebuah layanan dikatakan memiliki nilai yang tinggi atau baik di mata pelanggannya jika mampu memberikan pengorbanan yang seminimal mungkin dengan kualitas dan manfaat yang semaksimal mungkin.

Pengaruh positif dan signifikan dalam temuan penelitian ini memperkuat penelitian Milfener et al. (2009) yang menyatakan bahwa nilai yang dirasakan oleh pelanggan menyebabkan suatu keputusan apakah pelanggan merasa puas atau tidak. McDougall dan Levesque (2000) dan Cronin et al. (2000) dalam Milfener et al. (2009) menyatakan bahwa nilai yang dirasakan adalah salah satu hal yang penting untuk mendapatkan keunggulan kompetitif dan dianggap menjadi prediktor signifikan dari kepuasan pelanggan. Kepuasan merupakan 
konsekuensi dari nilai yang dirasakan, karena kepuasan adalah perbandingan antara nilai yang diharapkan dan dirasakan. Pelanggan yang merasa bahwa jika suatu instansi atau perusahaan memberikan nilai yang lebih daripada instansi atau perusahaan lainnya maka dapat meningkatkan kepuasan pelanggan.

$$
\text { Penelitian Hidayat (2009) }
$$

mengemukakan bahwa nilai pelanggan memiliki pengaruh positif dan signifikan terhadap kepuasan pelanggan. Hal ini menunjukkan bahwa semakin baik nilai bagi pelanggan yang diberikan oleh instansi atau perusahaan maka pelanggan semakin merasa puas terhadap jasa tersebut. Monroe (2002) dalam Hidayat (2009) menyatakan bahwa nilai bagi pelanggan sebuah tradeoff antara persepsi pelanggan terhadap kualitas, manfaat dan pengorbanan yang dilakukan lewat pengorbanan yang dikeluarkan. Nilai bagi pelanggan juga dapat dilihat sebagai cerminan dari kualitas, manfaat dan pengorbanan yang diberikan untuk mendapatkan sebuah layanan. Sebuah layanan dikatakan mempunyai nilai yang tinggi di mata pelanggan apabila mampu memberikan kualitas dan manfaat yang baik serta pengorbanan yang seminimal mungkin.

Hasil yang sama dikemukakan dalam penelitian Lee et al. (2011) bahwa nilai pelanggan memiliki pengaruh positif dan signifikan terhadap kepuasan pelanggan. Hal ini dapat dilihat bahwa semakin baik nilai yang dirasakan bagi pelanggan, semakin tinggi kepuasan pelanggan. Instansi atau perusahaan harus terlebih dulu memberikan nilai yang lebih baik untuk dapat meningkatkan kepuasan pelanggan. Kualitas layanan yang baik juga dapat meningkatkan kepuasan pelanggan melalui nilai yang dirasakan oleh pelanggan.

\section{Pengujian Hipotesis 4}

Kualitas layanan berpengaruh positif terhadap loyalitas pelanggan dengan nilai koefisien jalur sebesar 0,873 dan nilai $p$-value sebesar 0,000 ( $p$-value <

0,05 ) serta nilai $t$-hitung sebesar 6,192 (nilai $t$ hitung > 1,96) maka pengujian dapat dikatakan signifikan, sehingga $\mathrm{H} 0$ ditolak. Hal ini menunjukkan bahwa semakin baik kualitas layanan maka loyalitas pelanggan semakin meningkat.

Kualitas layanan yang baik dapat membuat pelanggan melakukan pembelian ulang di masa mendatang dan merekomendasikan layanan klinik dr. Sumakto, Sp. $A(K)$ kepada orang-orang

terdekat dari pelanggan. Loyalitas adalah komitmen untuk tetap melakukan kunjungan ke klinik dr. Sumakto, Sp. A(K) walaupun dipengaruhi oleh situasi dan tawarantawaran pemasaran yang dilakukan oleh klinik kesehatan lain dan mempunyai potensi bagi beralihnya pelanggan.

Pengaruh posiftif dalam hasil penelitian ini memperkuat penelitian

Tuhumena et al. (2008), Laohasirichaikul et al. (2010) dan Kesuma et al. (2013). Penelitian terdahulu dari Tuhumena et al. (2008) menemukan bahwa kualitas layanan berpengaruh signifikan terhadap loyalitas pelanggan. Hal ini menunjukkan bahwa untuk meningkatkan loyalitas pelanggan maka kualitas layanan yang diberikan harus sesuai dengan harapan pelanggan. Oliver (1997) dalam Tuhumena et al. (2008) menyatakan bahwa loyalitas dari aspek perilaku adalah komitmen seorang pelanggan untuk membeli produk atau jasa yang sama walaupun dipengaruhi oleh situasi dan tawaran-tawaran pemasaran yang dilakukan oleh instansi atau perusahaan jasa lain yang mempunyai potensi bagi beralihnya pelanggan.

Penelitian Laohasirichaikul et al. (2010) menyatakan bahwa kualitas layanan memiliki pengaruh positif dan signifikan terhadap loyalitas pelanggan. Faktor penentu dari kualitas layanan adalah kepuasan pelanggan dan loyalitas pelanggan. Oleh karena itu, perusahaan harus mempekerjakan orang yang tepat dan ahli untuk melayani pelanggannya karena pelangganlah yang akan memberikan kontribusi melakukan pembelian ulang dan merekomendasikan kepada orang lain atau tidak.

Hasil yang sama dikemukakan oleh Kesuma et al. (2013) bahwa kualitas layanan memberikan pengaruh positif dan signifikan terhadap loyalitas pelanggan.

Kualitas layanan memiliki peran penting untuk meningkatkan loyalitas pelanggan, 
karena adanya tingkat persaingan yang sangat ketat. Instansi atau perusahaan harus selalu berusaha meningkatkan kualitas layanan dalam rangka untuk meningkatkan loyalitas pelanggan yang pada akhirnya mendatangkan keuntungan.

\section{Pengujian Hipotesis 5}

Nilai pelanggan berpengaruh negatif terhadap loyalitas pelanggan dengan nilai koefisien jalur sebesar (-

0,322 ) dan nilai $p$-value sebesar 0,037 ( $p$-value $<0,05)$ serta nilai $t$-hitung sebesar

2,131 (nilai t-hitung > 1,96) maka pengujian dapat dikatakan signifkan, sehingga $\mathrm{H} 0$ ditolak. Hal ini menunjukkan bahwa semakin baik nilai pelanggan maka loyalitas pelanggan semakin menurun dikarenakan nilai koefisien jalurnya negatif.

Pasien semakin bertambah usia sistem kekebalan tubuh akan semakin lama semakin sempurna sehingga pasien seiring bertambahnya usia pasien akan semakin jarang sakit. Pasien yang semakin jarang sakit mengakibatkan proses loyalitas yang menurun karena tidak semakin jarang terjadi proses pembelian ulang dan proses rekomendasi kepada orang lain. Hal inilah yang menyebabkan pengaruh negatif antara nilai terhadap loyalitas.

Penelitian ini memperkuat penelitian Hidayat (2009) yang membuktikan bahwa nilai berpengaruh signifikan terhadap loyalitas. Hanya saja, pada penelitian Hidayat (2009) membuktikan bahwa pengaruhnya positif dan signifikan yang berbeda pada penelitian ini dengan pengaruhnya negatif dan signifikan. Ketika pelanggan merasakan nilai dari layanan yang diberikan semakin baik maka akan timbul sikap loyalitas dari pelanggan.

Penelitian Lertwannawit et al.

(2011) mengemukakan bahwa nilai pelanggan memiliki hubungan positif dan signifikan. Nilai layanan merupakan faktor penting dalam loyalitas. Ketika pelanggan memiliki persepsi tinggi terhadap nilai layanan, loyalitas juga akan meningkat dalam hal word of mouth, merekomendasikan layanan kepada orang lain. Penelitian ini ditemukan hasil yang berbeda dengan penelitian terdahulu bahwa pengaruh yang ditunjukkan adalah negatif dan signifikan antara variabel nilai pelanggan terhadap loyalitas pelanggan.

\section{Pengujian Hipotesis 6}

Kepuasan pelanggan berpengaruh positif terhadap loyalitas pelanggan dengan nilai koefisien jalur sebesar 0,227 dan nilai $p$ value sebesar 0,157 ( $p$-value

$>0,05$ ) dan nilai $t$-hitung sebesar 1,433 (nilai $t$ $<1,96)$ maka pengujian dapat

dikatakan tidak signifkan sehingga $\mathrm{H} 0$

diterima. Hal ini menunjukkan bahwa

semakin baik kepuasan pelanggan maka tidak begitu mempengaruhi loyalitas pelanggan.

Manusia bersifat individual, reaksi dari suatu pengobatan yang diberikan

kepada individu satu akan berbeda reaksi dengan individu yang lain. Jadi, ketika

pelanggan ingin merekomendasikan kepada orang lain, pelanggan lebih menahan diri dan tidak percaya diri untuk

menginformasikan kepada orang lain.

Penelitian ini juga memperkuat hasil penelitian dari Patawayati et al.

(2013) yang membuktikan bahwa

kepuasan berpengaruh tidak signifikan terhadap loyalitas. Obyek studi yang

dilakukan juga sama yaitu pada industri

kesehatan tepatnya pada Rumah Sakit Umum Sulawesi Tenggara pada pasien rawat inap. Indikator dari loyalitas yang digunakan yaitu word of mouth dan patient complain. Pasien yang merasa puas terhadap layanan yang diberikan belum tentu loyal terhadap Rumah Sakit tersebut. Alasannya manusia bersifat individual terhadap hasil pengobatan yang diberikan karena belum tentu pengobatan yang diberikan pada individu satu akan berdampak sama dengan individu lain. Sampel penelitian terfokus pada pasien rawat inap di RSUD Sulawesi Tenggara menunjukkan kepuasan berpengaruh tidak signifikan terhadap loyalitas disebabkan pasien rawat inap yang puas terhadap layanan yang diberikan oleh rumah sakit baik dari segi fasilitas fisik ataupun non fisik tidak memberikan rasa loyalitasnya baik dari indikator word of mouth (WOM) maupun patient complain (komplain dari pasien). 


\section{KESIMPULAN DAN SARAN \\ Kesimpulan}

Berdasarkan hasil penelitian, hasil analisis data, dan pembahasan hasil penelitian serta pengujian hipotesis yang dilakukan, maka dapat ditarik kesimpulan penelitian ini sebagai berikut:

1. Kualitas layanan berpengaruh signifikan terhadap nilai pelanggan.

2. Kualitas layanan berpengaruh signifikan terhadap kepuasan pelanggan.

3. Nilai pelanggan berpengaruh signifikan terhadap kepuasan pelanggan.

4. Kualitas layanan berpengaruh signifikan terhadap loyalitas pelanggan.

5. Nilai pelanggan berpengaruh signifikan terhadap loyalitas pelanggan.

6. Kepuasan pelanggan berpengaruh tidak signifikan terhadap loyalitas.

\section{Saran}

Hasil penelitian ini diharapkan memberikan kontribusi praktis, baik bagi klinik dr. Sumakto, Sp. A(K) maupun akademisi peneliti, berupa saran-saran konkrit yang mungkin dapat direalisasikan, antara lain :

1. Penelitian ini masih memungkinkan untuk dikembangkan dalam menguji ulang model penelitian dengan menambah variabel baru, seperti kepercayaan dan komitmen. Selain itu, juga dapat ditambahkan indikator pada variabel kualitas layanan karena dalam penelitian ini yang digunakan ada 5 indikator. Indikator dalam kualitas layanan yang bisa ditambahkan yaitu courtesy (kesopanan), communication (komunikasi), understanding the customer (memahami pelanggan).

2. Penelitian mendatang diharapkan mampu mengembangkan konseptual dan pemodelan kajian ini pada objekobjek kajian penelitian yang lebih luas tetapi masih dalam bidang atau industri jasa kesehatan yang lebih luas misalnya suatu poliklinik yang cakupannya lebih luas dengan sampel penelitian yang lebih besar pula

3. Klinik dr. Sumakto, Sp. A(K) diharapkan dapat meningkatkan kepuasan pelanggan dengan berbagai usaha, baik dari segi peningkatan kualitas layanan maupun dari nilai yang dirasakan. Apabila terjadi komplain dari pelanggan maka sebagai penyedia jasa yang baik tetap harus mendengarkan keluhan dari pelanggan. 


\section{DAFTAR PUSTAKA}

Alfin, Rita. (2013) Pengaruh Kualitas Layanan dan Kualitas Produk terhadap Citra Perusahaan, Kepuasan, Nilai, Kepercayaan dan Loyalitas Pelanggan (Studi pada Nasabah Tabungan Plus (Taplus) BNI Provinsi Jawa Timur). Disertasi, Fakultas Ilmu Administrasi Bisnis,

Universitas Brawijaya.

Barnes, James G. (2003). Secrets of

Customer Relationship Management.

Diterjemahkan oleh

Andreas Winardi, S.Pd. Andi.

Yogyakarta.

Chaniotakis, Ioannis E. and Constantine

Lymperopoulos. (2009). Sevice Quality Effect on Satisfaction

and Word of Mouth in the Health Care Industry". Managing Service Quality,

Vol. 19, No. 2, 2009, pp.229-241.

Engel, James F., Roger D. Balckwell, dan Paul W. Miniard. (1995). Perilaku Konsumen,

Jilid 1 dan

Jilid 2. Edisi Ke enam. Alih Bahasa

Drs. F.X Budiyanto. Jakarta, Binarupa

Aksara.

Fornell, Claes, Michael D. Johnson, Eugene

W. Anderson, Jaesung Cha and Barbara Everitt Bryant. (1996). The American Customer Satisfaction Index: Nature Purpose and Finding. Journal of Marketing, Oktober, pp. 7-17.

Hidayat, Rachmad. (2006). Pengaruh Kualitas Layanan, Kualitas Produk dan Nilai Bagi Nasabah terhadap Kepuasan dan Loyalitas Nasabah Bank Mandiri di Jawa Timur. Jurnal Manajemen dan Kewirausahaan, Vol. 11, No. 1, pp: 5972.

Huriyati, Ratih. (2005). Bauran Pemasaran

dan Loyalitas Konsumen. Bandung, CV.

Alfabeta. Kesuma, Ida Ayu Werdiningsih,

Djumilah Hadiwidjojo, Ni Luh Putu

Wiagustini dan Fatchur Rohman.

(2013). Service Quality Influence on

Patient Loyality : Customer

Relationship Management as

Mediation Variable (Study on Private

Hospital Industry in Denpasar).

International Journal of

Business and Commerce, (ISSN: 2225-

2436), Vol. 2, No.12: Aug 2013[01-14].

Kotler, Phillip. (1997). Manajemen

Pemasaran Analisis, Perencanaan, Implementasi, dan Kontrol. Jilid II Edisi Kesembilan, Terjemahan Hendra
Teguh, SE. AK dan Ronny, SE. AK, Jakarta, Penhalindo.

Laohasirichaikul, Bunthuwun, Sirion Chaipoopirutana and Howard Combs. (2010). Effective Customer Relationship Management of Health Care : A Study of the Perceptions of Service Quality, Corporate Image, Satisfaction, and Loyality of Thai Outpatients of Private Hospitals in Thailand. Proceedings of ASBBS, Volume 17, Number 1.

Lee, Wan-I and Chi Lung Lee. (2011). An Innovative Information and Relationship Between Service Quality, Customer Value, Customer Satisfaction and Purchase Intention. International Journal of Innovative Computing, Information and Control, ISSN 13494198, Volume 7 Number 7A, pp.35713581 .

Lertwannawit, Ph.D, Aurathai, Suan Dusit

Rajabhat and Nak Gulid, Ph.D.,

Srinakharinwirot. (2011).

International Tourists Service Quality

Perception and Behavioral Loyality

Toward Medical

Tourism In Bangkok Metropolitan Area. The Journal of Applied Business Research, Volume

27, Number 6.

Lovelock, Christoper. (2004). Services

Marketing : People, Technology, Strategy.

Second Edition.

Canada, Perason Education.

Lupiyoadi, Rambat dan Hamdani, A.

(2006). Manajemen Pemasaran Jasa.

Jakarta, Salemba Empat.

Milfelner, Borut, Boris Snoj and Aleksandra Pisnik Korda. (2009). Measurement of Perceived Quality, Perceived Value, Image, and Satisfaction Interrelations of Hotel Services : Comparison of Tourists From Slovenia and Italy. Drug Istraz Zagreb, God. 20, Br. 3 (113), Str. 605-624.

Padma, Panchapakesan, Chandrasekharan Rajendran and Prakash Sai Lokachari. (2010). Service Quality and Its Impact on Customer Satisfaction in Indian Hospitals Perspectives of Patients and Their Attendants. Benchmarking: An International Journal, Vol. 17 No. 6, pp. 807-841.

Palilati, Alida. (2004). Pengaruh Tingkat Kepuasan Terhadap Loyalitas Nasabah Tabungan

Perbankan di Wilayah Etnik Bugis.

Analisis, Volume 1, Nomor 2. 
Parasuraman, Berry and Zeithaml (1988).

Servqual: A Multiple Item for Measuring Customer

Perception of Service Quality. Journal of Retailing. 64. Pp. 12-40.

Patawayati, Djumilah Zain, Margono Setiawan and Mintarti Rahayu. (2013). Patient Satisfaction, Trust and Commitment: Mediator of Service Quality and Its Impact on Loyalty (An Empirical Study in Southeast Sulawesi Public Hospitals). OSR Journal of Business and Management (IOSR- JBM), Volume 7, Issue 6, PP 01-14.

Razavi, Seyed Mostafa, and Hossein Safari. (2012). Relationships Among Service Quality, Customer Satisfaction and Customer Perceived Value: Evidence from Iran's Software Industry. Journal of Management and Strategy, Vol. 3, No. 3.Singarimbun, Masri dan Sofian Effendi. (2008). Metode Penelitian Survei. Cetakan Ke Sembilan Belas. Jakarta, LP3ES.

Solimun. (2003). Structural Equation Modeling (SEM) Lisrel dan Amos: Aplikasi di Manajemen, Ekonomi Pembangunan, Psikologi Sosial, Kedokteran dan Agrokompleks. Edisi I.

Penerbit Universitas Negeri Malang.

Suki, Norazah Mohd, Jennifer Chiam Chwee Lian and Norbayah Mohd Suki. (2009). Do Patients Perceptions Exceed Their Expectations in Private Healthcare mpanies, Ltd. North America.
Settings? International Journal of Health Care Quality Assurance, Vol. 24 No. 1, pp. 42-56.

Tjiptono, Fandy. (2005). Pemasaran Jasa. Malang, Bayumedia Publishing. Tjiptono, Fandy. (2006). Pemasaran Jasa. Malang, Bayumedia Publishing.

Tuhumena, Ruben, Surachman, Eka Afnan Troena dan Margono Setiawan. (2008). Analisis Pengaruh Kualitas Layanan, Kepuasan, dan Loyalitas terhadap Niat Berperilaku Pasien Rumah Sakit Umum Daerah (RSUD) Jayapura. ISSN : 1693 - 5241.

Wright, Christopher H. Lovelock dan Lauren K., (2005). Manajemen Pemasaran Jasa.

\section{Edisi Bahasa}

Indonesia. Jakarta, PT Indeks.

$\mathrm{Wu}$, Chao Chan. (2011). The Impact of Hospital Brand Image on Service Quality, Pastient Satisfaction and Loyality. African Journal of Business Management, Vol. 5(12), pp. 48734882.

Yuniningsih. (2007). Pengaruh Kepuasan dan Hubungan Pemasaran terhadap Loyalitas Nasabah beberapa Bank di Surabaya. Jurnal Manajemen Akuntansi dan Bisnis, 5(3).

Zeithaml, Valarie A. and Marry Jo Bitner. (2003). Services Marketing. Integrating Customer Focus

Across The Firm. International Edition. McGraw-Hill Co 